\title{
Efficacy of sorafenib in patients with hepatocellular carcinoma after resection: a meta-analysis
}

\author{
Jin Shang ${ }^{1, *}$, Shanling Xu ${ }^{2, *}$, Jiaxing Zhang ${ }^{3}$, Xuting Ran ${ }^{4}$, Lang Bai ${ }^{1}$ and Hong Tang ${ }^{1}$ \\ ${ }^{1}$ Center of Infectious Diseases, West China Hospital, Sichuan University, Chengdu, Sichuan, China \\ ${ }^{2}$ Sichuan Cancer Hospital and Institute, Sichuan Cancer Center, School of Medicine, University of Electronic Science and \\ Technology of China, Chengdu, China \\ ${ }^{3}$ Chinese Evidence-based Medicine Center, Sichuan University, Chengdu, China \\ ${ }^{4}$ West China Medical School, Sichuan University, Chengdu, Sichuan, China \\ *These authors contributed equally to this work and share Co-first authors
}

Correspondence to: Lang Bai, email: pangbailang@163.com

Keywords: hepatocellular carcinoma, liver resection, sorafenib, overall survival, recurrence

Received: January 12, 2017 Accepted: September 13, $2017 \quad$ Published: September 28, 2017

Copyright: Shang et al. This is an open-access article distributed under the terms of the Creative Commons Attribution License 3.0 (CC BY 3.0), which permits unrestricted use, distribution, and reproduction in any medium, provided the original author and source are credited.

\section{ABSTRACT}

Background: The prognosis of hepatocellular carcinoma remains poor even after curative resection and it has no effective adjuvant therapy.

Aim: This meta-analysis aimed to assess efficacy of sorafenib as adjuvant therapy for patients with hepatocellular carcinoma after resection.

Materials and methods: A systematic search was conducted of Medline, Embase, Web of Science, Cochrane Library, Chinese Wanfang database, Chinese biological and medical database, China National Knowledgeand the Internet, data from 5 studies that included 296 participants were analyzed. The primary outcome was overall survival. Secondary outcomes included recurrence rate and mortality rate.

Results: In the comparison of sorafenib versus control, no significant difference in overall survival (hazard ratio $1.39,95 \%$ confidence interval $[\mathrm{CI}] 0.71-2.74, P=0.34$ ) or recurrence rate [risk ratio ( $R R) 0.81,95 \% \mathrm{CI} ; 0.65-1.01, P=0.06$ ) was found. For mortality rate, subgroup analysis was conducted according to study type, only in subgroup 2 , the $R R$ was significantly reduced $(0.66,95 \% C I ; 0.51-0.87, P=0.003)$ in studies.

Conclusions: In this meta-analysis, sorafenib achieves no significant benefit in any of the endpoints except a lower mortality rate in subgroup analysis, indicating that there is no convincing evidence of sorafenib as an effective adjuvant therapy in patients with hepatocellular carcinoma after resection.

\section{INTRODUCTION}

Hepatocellular carcinoma (HCC) is the sixth most common solid cancer, causing 745,000 deaths worldwide annually, which ranks second as the cause of death among cancers. Moreover, recent data show an increasing trend in its incidence in many countries [1]. Most risk factors are known, such as chronic hepatitis B virus (HBV), chronic hepatitis $\mathrm{C}$ virus, alcohol consumption, nonalcoholic steatohepatitis, and diabetes [2]. Additionally, the development of a diagnosis technique of HCC by imaging or biopsy analysis enables to diagnose $\mathrm{HCC}$ larger than $10 \mathrm{~mm}$ [3]. However, the management of HCC remains a challenge. Liver transplantation, liver resection, and liver ablation are considered potentially curative treatments. Liver resection applies to patients with early-stage HCC with preserved liver function, and it is the only option for large $\mathrm{HCC}$ but with preserved hepatic function. Moreover, 
recent research reports that liver resection, compared with ablation, is also the preferred management even for very early-stage small cancers [4]. Additionally, liver resection has some advantages over transplantation such as organ saving, lower costs, and lower dropout rate. However, the recurrence rate after liver resection is still as high as $70 \%$ at 5 years [5] with 5-year survival rates ranging from $60 \%$ to $80 \%[6,7]$. Thus, a high recurrence rate and unsatisfactory long-term prognosis of HCC highlight the need for adjuvant therapy.

Since HCC shows resistance to chemotherapy and radiotherapy, sorafenib, as the only standard oral multikinase inhibitor approved by the U.S. Food and Drug Administration and European Medicines Agency for HCC, has been demonstrated to benefit overall survival for HCC [8]. Also sorafenib has been proven to improve prognosis of advanced renal-cell carcinoma [9] and advanced thyroid cancer [10]. Furthermore, experiments in vivo show that sorafenib inhibits tumor growth and prevents metastatic recurrence after resection of HCC in nude mice [11]. However, recent opinions that sorafenib as adjuvant therapy could benefit patients with $\mathrm{HCC}$ after resection are still controversial [12-16].

To solve this problem, we conducted this metaanalysis to estimate the effectiveness of sorafenib as adjuvant therapy for $\mathrm{HCC}$ after liver resection.

\section{RESULTS}

After screening and reviewing articles, five studies were selected. Characteristics of included studies are summarized in Table 1. Three of the studies were retrospective studies, one was an open-label controlled phase II trial, and one was a prospective controlled trial. All were conducted in patients with HCC after liver resection, and the dose of sorafenib varied from $200 \mathrm{mg}$ to $800 \mathrm{mg} /$ day. (Table 1).

Main characteristics of patients treated with sorafenib for HCC after liver resection are shown in Table 2. All included articles were published after 2014. A total of 109 patients were included, and the sample size varied from
12 to 32 patients, the range of median age was from 48.00 to 61.43 , while the range of percentage of male patients was from $78.13 \%$ to $100 \%$. The percentage of hepatitis B surface antigen positive rate ranged from $25 \%$ to $87.50 \%$, and the mean tumor size range varied from $5.7 \mathrm{~cm}$ to 9.8 cm. (Table 2.)

\section{Effects of sorafenib on outcome}

Regarding overall survival as a primary outcome, four articles were reviewed and analyzed. After we pooled the data, adjuvant therapy using sorafenib for HCC after resection was prone to achieve longer overall survival with the hazard ratio of 1.39 , but the $95 \%$ CI of hazard ratio was 0.71 to $2.74, P=0.34$, which showed that the benefit did not have statistical significance; with regard to heterogeneity analysis, both Cochran's $Q$ statistic and $\mathrm{I}^{2}$ showed no statistical significance. (Figure 1).

Secondary outcomes included recurrence rate and mortality rate. Four articles were analyzed, and data about recurrence rate were pooled: sorafenib versus control for $\mathrm{HCC}$ after resection was prone to achieve lower recurrence rate; however, the risk ratio was 0.81 , and the $95 \% \mathrm{CI}$ was 0.65 to 1.01 , with no statistical significance $(P=0.06)$. With regard to heterogeneity analysis, both Cochran's $Q$ statistic and $\mathrm{I}^{2}$ showed no statistical significance. (Figure 2).

With regard to mortality rate, Cochran's $Q$ statistical analysis showed $\mathrm{df}=4(P=0.04)$ and $\mathrm{I}^{2}=60 \%$, which indicated high heterogeneity; after analysis of factors causing heterogeneity, subgroup analysis was conducted according to study design, and the heterogeneity of each group was then found to be low. Sorafenib for patients with $\mathrm{HCC}$ after resection achieved low mortality rate, with a risk ratio of 0.76 (CI 95\% $0.38-1.54$, no statistical significance) in clinical trials group, while the risk ratio was 0.66 (CI 95\% 0.51-0.87, $P=0.003$ ), with statistical significance in the observation studies group. (Figure 3 ).

Sensitivity analyses of all outcomes were conducted. No reverse emerged when trimming one study at a time, indicating the results were stable.

Adverse events related to sorafenib occurred at a high rate, with hand-foot skin reaction, diarrhea, alopecia,

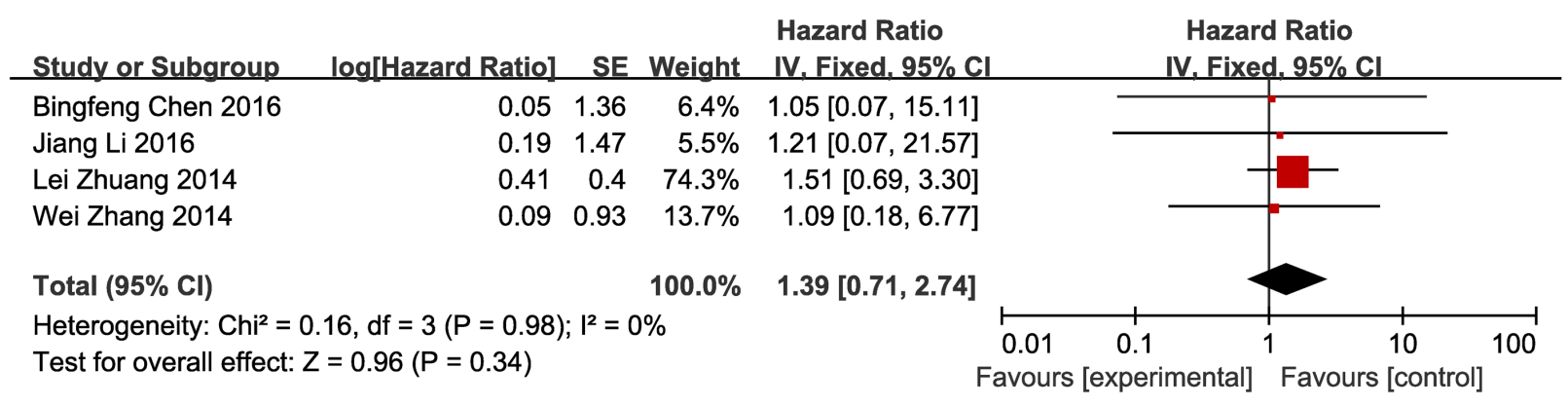

Figure 1: Efficacy of sorafenib for overall survival Shows forest plot of hazard ratio of overall survival of patients with hepatocellular carcinoma after resection who treated with sorafenib versus control. Data of 4 studies were pooled using fixedeffects model. Studies are sorted by publication year. 
Table 1: Characteristics of studies included in the meta-analysis

\begin{tabular}{|c|c|c|c|c|c|c|c|}
\hline $\begin{array}{c}\text { Authors } \\
\text { (year) }\end{array}$ & Design & Population & $\begin{array}{c}\text { Dose of } \\
\text { sorafenib }\end{array}$ & $\begin{array}{c}\text { Treatment } \\
\text { duration }\end{array}$ & $\begin{array}{l}\text { Follow-up } \\
\text { time(range) }\end{array}$ & Outcomes & References \\
\hline $\begin{array}{c}\text { Wei } \\
\text { Zhang (2014) }\end{array}$ & $\begin{array}{l}\text { Retrospective } \\
\text { with historical } \\
\text { control }\end{array}$ & $\begin{array}{l}\text { Patients with HCC } \\
\text { after curative } \\
\text { resection }\end{array}$ & $\begin{array}{c}400 \mathrm{mg} \\
\text { twice daily }\end{array}$ & One month & - & $\begin{array}{l}\text { Overall survival; } \\
\text { recurrence rate and } \\
\text { mortality rate }\end{array}$ & 12 \\
\hline $\begin{array}{c}\text { Shen-Nien } \\
\text { Wang (2014) }\end{array}$ & $\begin{array}{c}\text { Open-label, } \\
\text { controlled phase } \\
\text { II trail }\end{array}$ & $\begin{array}{l}\text { Patients with HCC } \\
\text { after curative } \\
\text { resection }\end{array}$ & $400 \mathrm{mg}$ q.d & 4 months & $\begin{array}{l}9.5-30.2 \\
\text { months }\end{array}$ & $\begin{array}{c}\text { Recurrence rate; } \\
\text { mortality rate }\end{array}$ & 13 \\
\hline $\begin{array}{l}\text { Lei Zhuang } \\
\text { (2014) }\end{array}$ & $\begin{array}{l}\text { Retrospective } \\
\text { with historical } \\
\text { control }\end{array}$ & $\begin{array}{l}\text { Patients with } \mathrm{HCC} \\
\text { after curative } \\
\text { resection }\end{array}$ & $\begin{array}{l}400 \mathrm{mg} \\
\text { twice daily }\end{array}$ & - & 13-44 months & $\begin{array}{l}\text { Overall survival; } \\
\text { mortality rate }\end{array}$ & 14 \\
\hline Jiang Li (2016) & $\begin{array}{l}\text { Retrospective } \\
\text { with historical } \\
\text { control }\end{array}$ & $\begin{array}{l}\text { BCLC stage } \mathrm{C} \\
\text { HCC after curative } \\
\text { resection }\end{array}$ & $\begin{array}{c}200-800 \\
\mathrm{mg} / \mathrm{d}\end{array}$ & One month & 9-54 months & $\begin{array}{l}\text { Overall survival; } \\
\text { recurrence rate; } \\
\text { mortality rate }\end{array}$ & 15 \\
\hline $\begin{array}{c}\text { Bingfeng Chen } \\
(2016)\end{array}$ & $\begin{array}{l}\text { Prospective } \\
\text { controlled trail }\end{array}$ & $\begin{array}{l}\text { Patients with HCC } \\
\text { after curative } \\
\text { resection }\end{array}$ & $\begin{array}{l}400 \mathrm{mg} \\
\text { twice daily }\end{array}$ & 6 months & $36-60$ months & $\begin{array}{l}\text { Overall survival; } \\
\text { recurrence rate; } \\
\text { mortality rate }\end{array}$ & 16 \\
\hline
\end{tabular}

HCC: Hepatocellular carcinoma

and hypertension as the most common side-effects. All patients recovered and no grade 4 adverse events or drugrelated deaths occurred. No patients withdrew from the treatment of sorafenib (Table 3).

\section{DISCUSSION}

This is the first meta-analysis on sorafenib as adjuvant therapy for HCC after resection. The metaanalysis included a diverse population from different regions, though sorafenib was prone to achieve better outcomes, including longer overall survival, lower risk ratio, and lower mortality rate; however, only a significant lower mortality rate was found in observation studies through subgroup analysis, no statistically significant difference was found in other outcomes.

Adjuvant therapy is necessary for reducing recurrence rate of $\mathrm{HCC}$ after resection. However, there is no standard adjuvant therapy recommended yet, only interferon therapy showed its benefit but its side effect is nonnegligible. Current studies were mainly conducted on sorafenib monotherapy, there is no study on combination of sorafenib with other treatment as adjuvant therapy after liver resection yet and this could be a promising way in the future. Concerning sorafenib as monotherapy for $\mathrm{HCC}$ after liver resection, theoretically, it is worth investigating its adjuvant use to prevention of HCC recurrence for the reason that activation of the epidermal growth factor receptor, platelet-derived growth factor/receptor contributes to carcinogenesis, which is mediated by signaling pathways of angiogenesis and cell proliferation such as Ras/Raf/MEK/ERK [17]. Sorafenib as a multitargeted inhibitor was proven to inhibit them [18] and thought to be potentially effective in an adjuvant setting for HCC after resection. Contrary to theories, despite the effect of suppressing tumor and anti-angiogenic in advanced HCC, sorafenib did not show any benefit as an adjuvant therapy for HCC after resection.

These findings are similar to those of adjuvant sorafenib for other tumors such as renal carcinoma [19] and breast carcinoma [20]. Moreover, in patients with resected renal cell carcinoma, the addition of sorafenib shows substantial treatment discontinuation because of drug toxicity that grade 3 or worst adverse events

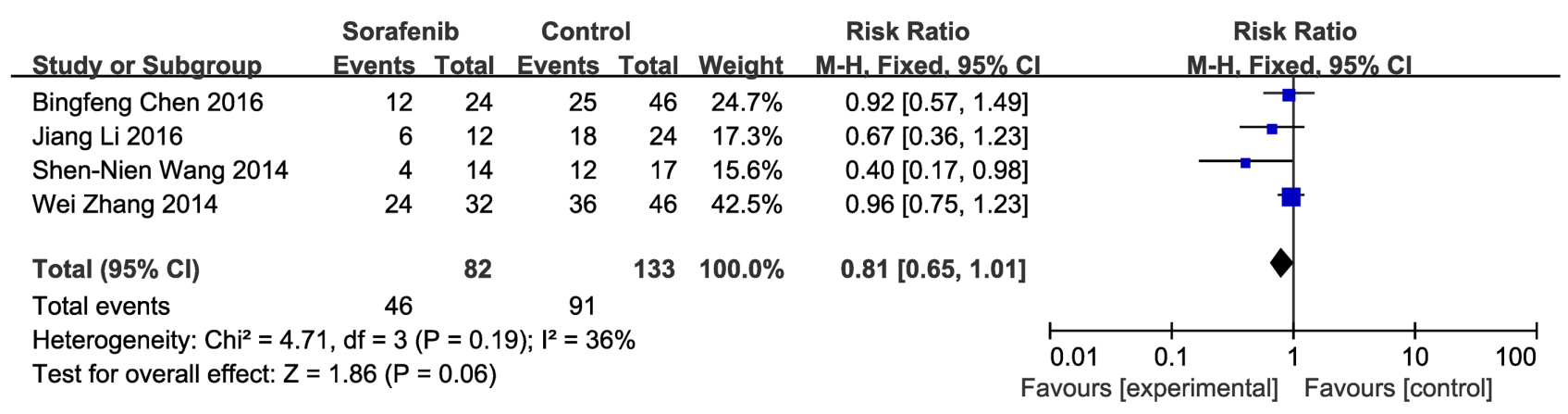

Figure 2: Efficacy of sorafenib for recurrence rate Shows forest plot of risk ratio of recurrence rate of patients with hepatocellular carcinoma after resection who treated with sorafenib versus control. Data of 4 studies were pooled using fixed-effects model. Studies are sorted by publication year. 
Table 2: Characteristics of patients treated with sorafenib for patients with hepatocellular carcinoma after resection

\begin{tabular}{|c|c|c|c|c|c|c|c|c|c|}
\hline Authors & Year & Region & Sample & $\begin{array}{l}\text { Median } \\
\text { Age }\end{array}$ & $\begin{array}{l}\text { Males } \\
(\%)\end{array}$ & $\begin{array}{c}\text { Hepatitis } \\
\text { status } \\
\text { (HBV/non- } \\
\text { HBV) }\end{array}$ & $\begin{array}{c}\text { Mean } \\
\text { tumor Size } \\
(\mathrm{cm})\end{array}$ & $\begin{array}{c}\mathrm{AFP}(\geqq 400 /<400 \\
\mathrm{ng} / \mathrm{mL})\end{array}$ & Cirrhosis(\%) \\
\hline $\begin{array}{l}\text { Bingfeng } \\
\text { Chen }\end{array}$ & 2016 & China & 24 & 48.00 & $91.67 \%$ & - & - & - & $62.5 \%$ \\
\hline Jiang Li & 2016 & China & 12 & 49.80 & $100.00 \%$ & $3 / 9$ & 9.8 & $8 / 4$ & 0 \\
\hline Lei Zhuang & 2014 & China & 27 & 48.19 & $92.59 \%$ & $23 / 4$ & 7.84 & $15 / 12$ & $22.2 \%$ \\
\hline $\begin{array}{l}\text { Shen-Nien } \\
\text { Wang }\end{array}$ & 2014 & China & 14 & 61.43 & $92.86 \%$ & $10 / 4$ & 6.26 & $\begin{array}{c}16 / 16(\geqq 20 /<20 \mathrm{ng} / \\
\mathrm{mL})\end{array}$ & 0 \\
\hline Wei Zhang & 2014 & China & 32 & 54.00 & $78.13 \%$ & $28 / 4$ & 5.7 & - & - \\
\hline Range & $\begin{array}{c}2014- \\
2016\end{array}$ & China & $12-32$ & $\begin{array}{c}48.00 \\
61.43\end{array}$ & $\begin{array}{l}78.13 \%- \\
100.00 \%\end{array}$ & $3-28 / 4-9$ & $5.7-9.8$ & $8-16 / 4-16$ & $0-62.5$ \\
\hline
\end{tabular}

HBV: hepatitis B virus

Table 3: Sorafenib-related adverse events

\begin{tabular}{|c|c|c|c|c|c|}
\hline & Bingfeng Chen (2016) & Jiang Li (2016) & Lei Zhuang (2014) & $\begin{array}{c}\text { Shen-Nien Wang } \\
\text { (2014) }\end{array}$ & Wei Zhang (2014) \\
\hline Sample* & 24 & 12 & 27 & 14 & 32 \\
\hline Dose reduction & - & 0 & 4 & 0 & 2 \\
\hline Treatment discontinuation & 0 & 0 & 0 & 0 & 0 \\
\hline Hand-foot skin reaction & 10 & 11 & - & 14 & - \\
\hline Diarrhea & 7 & 10 & - & 8 & - \\
\hline Alopecia & 9 & 0 & - & 14 & - \\
\hline Rash & 6 & 0 & - & 1 & - \\
\hline Hypertension & 5 & 10 & - & 3 & - \\
\hline Anorexia & 14 & 0 & - & 3 & - \\
\hline Fatigue & 12 & 0 & - & 3 & - \\
\hline Grade 3 adverse events ${ }^{\#}$ & - & - & 6 & 0 & $6^{\Delta}$ \\
\hline Hand-foot skin reaction & - & - & 4 & - & - \\
\hline Diarrhea & - & - & 2 & - & - \\
\hline Grade 4 adverse events ${ }^{\&}$ & - & - & 0 & 0 & 0 \\
\hline $\begin{array}{l}\text { Occurrence rate of grade } 3 \\
\text { or worst Adverse events }\end{array}$ & - & - & 0.22 & 0 & 0.19 \\
\hline
\end{tabular}

*Sample means number of patients treated with sorafenib in publications.

- means data were not reported in included publications.

\#Grade 3 Rash: hand-foot skin reaction is defined as ulcerative dermatitis or skin changes with pain interfering with function, Grade 3 diarrhea is defined as increase of $\geq 7$ stools per day over baseline; incontinence; IV(intravenous) fluids $\geq$ 24 hours; hospitalization; severe increase in ostomy output compared to baseline; inferring with activities of daily living.

${ }^{\&}$ Grade 4 diarrhea is defined as life-threatening consequences. ${ }^{\Delta}$ Not mentioned specifically.

were reported in $72 \%$ of patients treated with sorafenib. However, in our study, an occurrence rate of grade 3 or worse adverse events range from 0 to 0.22 , only six patients received reduced sorafenib, and no patients withdrew from sorafenib treatment, which indicates that sorafenib was generally safe in patients with HCC after resection; thus, our study results were not affected.
With regard to sorafenib as adjuvant treatment, the unsatisfied efficiency is mainly attributed to the following: First, HBV DNA level was one of the most important acknowledged risk factors for postoperative $\mathrm{HCC}$ recurrence [21]. Antiviral treatment after resection is essential for either survival benefit or reducing recurrence [22]. In our study, four included articles reported the proportion of HBV-related HCC. 
However, the use of antiviral therapy was not elaborated. Therefore, it is uncertain whether efficiency of sorafenib was affected by HBV status. In other words, if patients with HBV-related HCC are not treated with antiviral therapy after resection, viral replication reaction and even liver failure is likely to occur.

Regarding other risk factors associated with survival of HCC after resection, microvascular invasion, tumor volume, platelet count, serum albumin, and sex have been reported to date [23]. Among these risk factors, microvascular invasion was considered the most important predictive factor for survival [24]. In addition, microvascular invasion is also an independent risk factor for early recurrence after resection [25]. Early recurrence and late recurrence are two different patterns. The important risk factor for late recurrence is cirrhosis [26]. Consequently, the issue was whether sorafenib as an adjuvant treatment could affect microvascular invasion and cirrhosis to benefit patients with HCC after resection.

Microvascular invasion (MVI) is mediated by a complex course called epithelial-mesenchymal transitions (EMT). EMT has been validated in HCC progression [27]. In brief, tumor cells acquire mesenchymal markers and produce specific proteases, and the specific proteases then lead to the degradation of extracellular matrix; further, the cell-to-cell adhesion decreases and apico-basal polarity losses facilitate the invasion [28]. Consequently, once EMT occurs, many pathways and molecules, such as E-cadherin, cytokeratins, Wnt pathway, and Notch pathway, lead to sorafenib resistance [29, 30]. Thus, the relationship between EMT and sorafenib resistance can explain why sorafenib did not benefit patients with MVI. Moreover, even though sorafenib can suppress tumor proliferation and angiogenesis mainly mediated by inhibiting Raf and VEGFR(vascular endothelial growth factor receptor), no evidence exists that it can prevent MVI. On the contrary, Raf inhibitor activated the ERK cascade signal [31], and VEGFR inhibitor accelerate the metastasis [32]. Whether the effects of sorafenib can sustain the progression need further confirmation. With regard to the other risk factor, cirrhosis, sorafenib could neither improve liver function nor treat cirrhosis. Consequently, the invalidity of sorafenib on the two main risk factors could explain the results of our study.

When comparing adjuvant sorafenib therapy to other curative treatments of HCC, it was reported that sorafenib is associated with an acceptable safety profile and survival benefit in patients with HCC suffering recurrence after liver transplantation [33]. Sorafenib might also benefit patients with HCC after resection; nevertheless, the status of hepatocyte, risk factors of recurrence, or prognostic factors are different. Hallmarks that include sustaining proliferative signaling, evading growth suppressors, and tumor-promoting inflammation, have changed in patients with HCC despite the resection [34].

In conclusion there were no significant differences in any of the endpoints except a lower mortality rate in subgroup analysis, indicating that this meta-analysis provides no convincing evidence that sorafenib is an effective adjuvant therapy in patients with HCC after resection. However, more prospective studies are required in the future, allowing this meta-analysis to be updated.

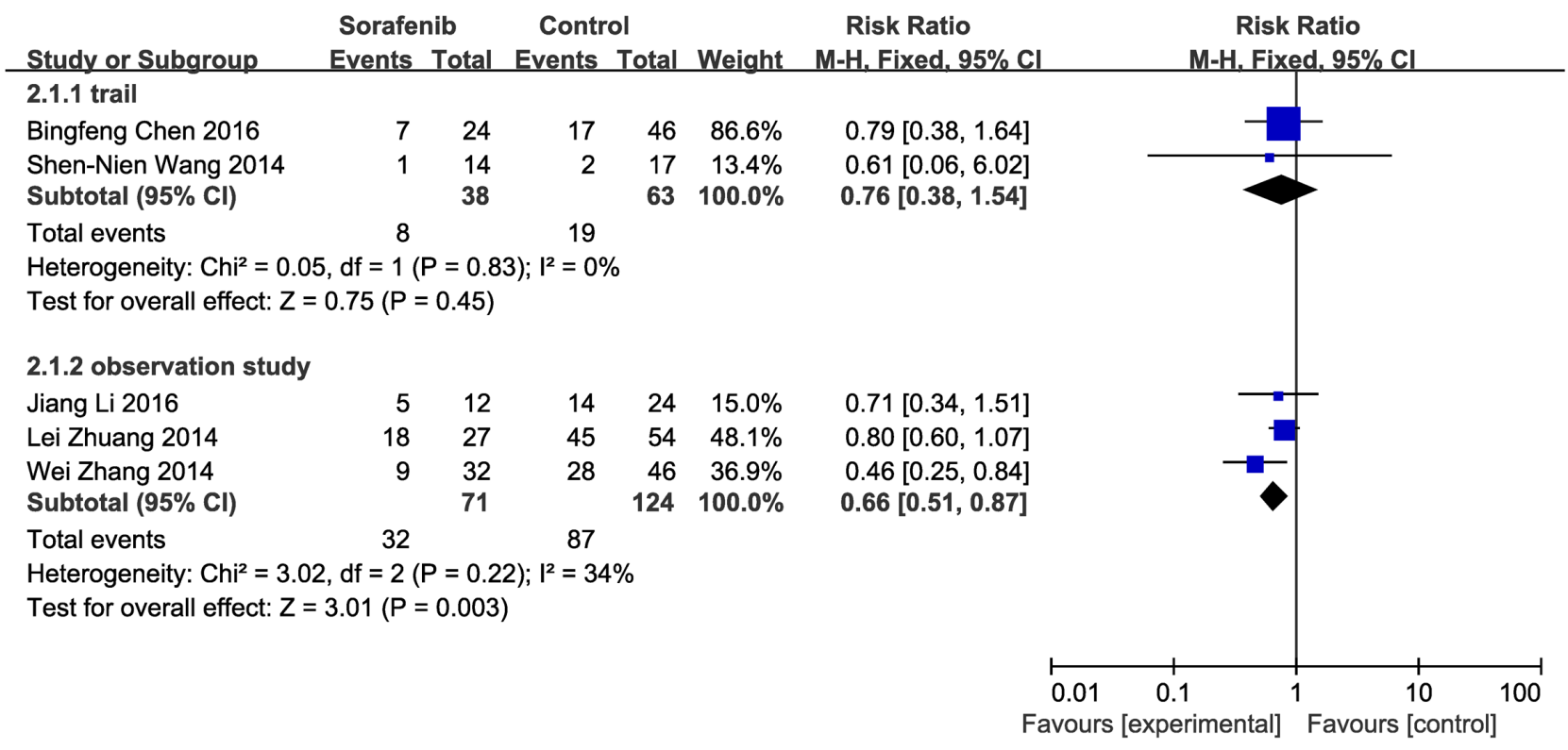

Figure 3: Efficacy of sorafenib for mortality rate. Shows forest plot of risk ratio of mortality rate of patients with hepatocellular carcinoma after resection who treated with sorafenib versus control. Subgroup analysis of 5 studies according to study typewere conducted because of the high heterogeneity when pooling all data. Data of each subgroup were pooled using fixed-effects model. Studies are sorted by publication year. 


\section{MATERIALS AND METHODS}

\section{Selection of trials}

This analysis was conducted according to the PRISMA (Preferred Reporting Items for Systematic Reviews and Meta-Analyses) statement. Publications were screened and identified through a search of Medline, Embase, Web of Science, Cochrane Library, Chinese Wanfang database, Chinese biological and medical database, China National Knowledge and the Internet. The search strategy was that patients (with HCC after liver resection) and intervention (sorafenib) searches were not limited by date but by English and Chinese language. Then, the title and abstract were screened, and the retrieved articles were further analyzed for their reference lists. Included criteria were full-length articles regarding the use of sorafenib for treatment of HCC after liver resection, including patients with $\mathrm{HCC}$ after liver resection. Case reports, ongoing studies, and articles with incomplete information were excluded. The primary outcome was overall survival. Secondary outcomes included recurrence rate and mortality rate. Among the 522 studies reviewed (Figure 4), 13 articles were selected, including 11 full-length articles. However, this meta- analysis includes only five full papers because the other six papers [35-40] did not regard selective outcome or possessed incomplete information.

\section{Review of trials}

Three independent investigators reviewed and evaluated the retrieved articles about patient characteristics, interventions, outcomes, and study validity. Controversies among investigators were not common and were solved by discussion or counseling evidence-based medicine experts. Quality of evidence for randomized studies was assessed according to the Cochrane Collaboration's tool for assessing risk of bias [41], and the Newcastle Ottawa Scale was used to assess quality of nonrandomized studies [42].

\section{Statistical analysis}

Summary hazard ratios, risk ratios, and $95 \%$ CIs were calculated using fixed effects models or random effects models based on heterogeneity and Cochran's Q statistic, and $\mathrm{I}^{2}$ was used to assess the heterogeneity across studies. Subgroup analysis stratified by study design was conducted. A $p$-value $<0.05$ was considered statistically significant. The sensitivity of meta-analysis was assessed by trimming one study, and the pooled results were then

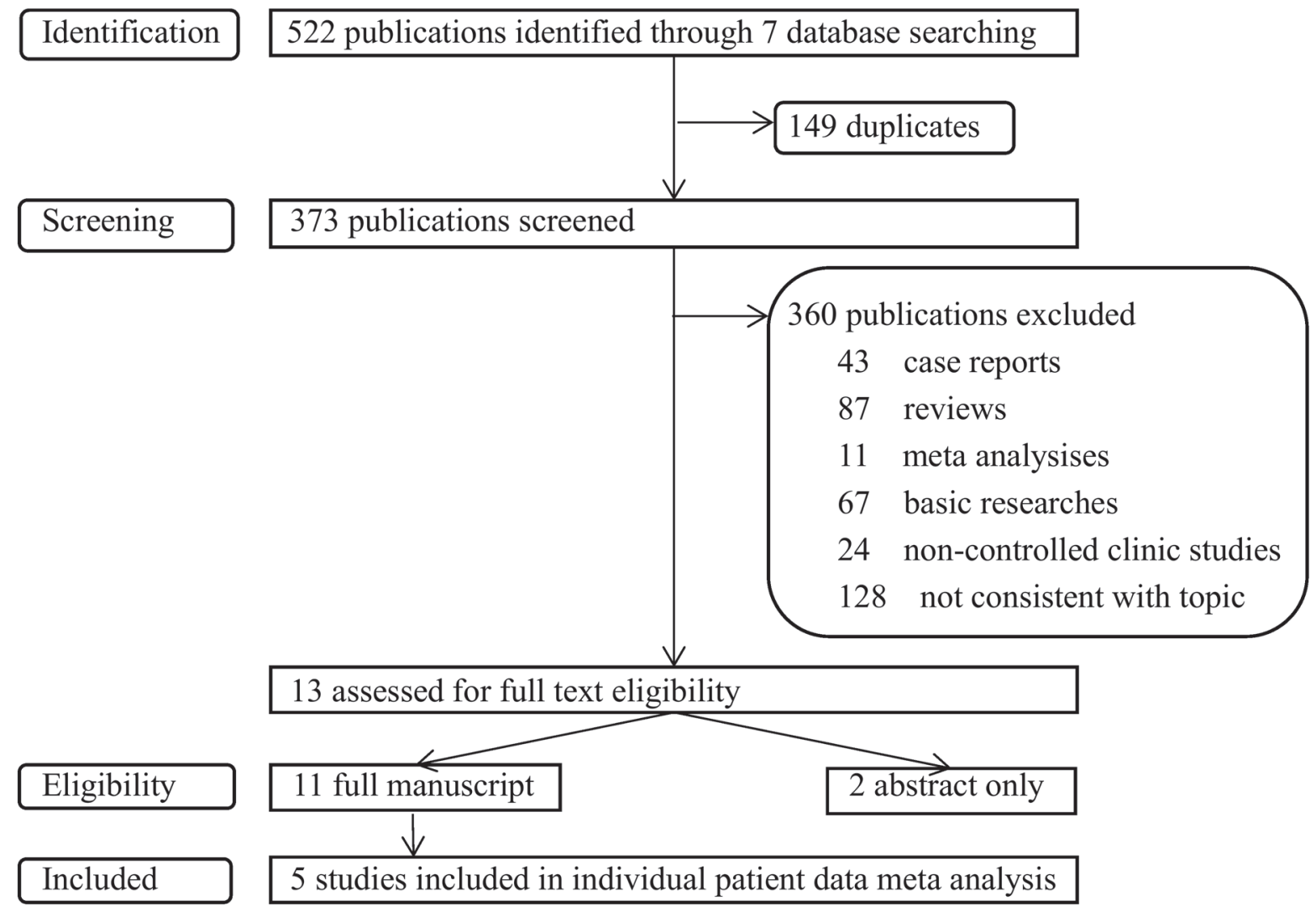

Figure 4: Flow diagram of studies indentified, screened, included and excluded Shows literature research and selection strategy following prisma flow diagram. 4 steps were conducted including identification, screening, eligibility, included. Inapplicable publications were excluded in each step and 5 publications were included at last. 
compared before and after the trimming. All analyses were performed by Review Manager Software.

\section{Abbreviations}

HCC; hepatocellular carcinoma; HBV; hepatitis B virus ;PRISMA ; Preferred Reporting Items for Systematic Reviews and Meta-Analyses; CI; confidence interval.

\section{Author contributions}

Jin Shang and Xu-ting Ran participated in searching, screening, assessing and including publications, Jin Shang and Shan-ling Xu participated in statistical analysis, any disagreement was resolved by Lang Bai, Shan-ling Xu and Jin Shang participated in writing the article, Jin Shang and Jiaxing Zhang participated in revising the manuscript and writing the response letter, Hong Tang and Lang Bai decided the research concept and design, also Lang Bai made critical revision and final approve of the article.

\section{ACKNOWLEDGMENTS}

None.

\section{CONFLICTS OF INTEREST}

There is no financial relationship between all authors and the organization that sponsored the research.

\section{FUNDING}

None.

\section{REFERENCES}

1. Ferlay J, Soerjomataram I Fau-Dikshit R, Dikshit R FauEser S, Eser S Fau-Mathers C, Mathers C Fau-Rebelo M, Rebelo M Fau-Parkin DM, Parkin Dm Fau-Forman D, Forman D Fau-Bray F, Bray F. Cancer incidence and mortality worldwide: sources, methods and major patterns in GLOBOCAN 2012. Int J Cancer. 2015; 136:E359-E86. https://doi.org/10.1002/ijc.29210.

2. Forner A, Llovet Jm Fau-Bruix J, Bruix J. Hepatocellular carcinoma. Lancet. 2012; 379:1245-55. https://doi.org/ https://doi.org/10.1016/S0140-6736(11)61347-0.

3. Darnell A, Forner A Fau-Rimola J, Rimola J Fau-Reig M, Reig M Fau-Garcia-Criado A, Garcia-Criado A Fau-Ayuso C, Ayuso C Fau-Bruix J, Bruix J. Liver Imaging Reporting and Data System with MR Imaging: Evaluation in Nodules $20 \mathrm{~mm}$ or Smaller Detected in Cirrhosis at Screening US. Radiology. 2015; 275:698-707. https://doi.org/10.1148/ radiol.15141132.

4. Wang Y, Luo Q, Li Y, Deng S, Wei S, Li X. Radiofrequency ablation versus hepatic resection for small hepatocellular carcinomas: a meta-analysis of randomized and nonrandomized controlled trials. PLoS One. 2014; 9:e84484. https://doi.org/10.1371/journal.pone.0084484.

5. Pang TC, Lam VW. Surgical management of hepatocellular carcinoma. World J Hepatol. 2015; 7:245-52. https://doi. org/10.4254/wjh.v7.i2.245.

6. European Association for the Study of the Liver EOfRaToC. EASL-EORTC clinical practice guidelines: management of hepatocellular carcinoma. J Hepatol. 2012; 56:908-43. https://doi.org/https://doi.org/10.1016/j.jhep.2011.12.001.

7. Bruix J, Sherman M. Management of hepatocellular carcinoma: an update. Hepatology. 2011; 53:1020-2. https:// doi.org/10.1002/hep.24199.

8. Cheng AL, Kang YK, Fau-Chen Z, Chen Z, Fau-Tsao CJ, Tsao CJ, Fau-Qin S, Qin S, Fau-Kim JS, Kim JS, Fau-Luo R, Luo R, Fau-Feng J, et al. Efficacy and safety of sorafenib in patients in the Asia-Pacific region with advanced hepatocellular carcinoma: a phase III randomised, doubleblind, placebo-controlled trial. Lancet Oncol. 2009; 10:2534. https://doi.org/10.1016/S1470-2045(08)70285-7.

9. Escudier B, Eisen T, Fau-Stadler WM, Stadler WM, FauSzczylik C, Szczylik C, Fau-Oudard S, Oudard S, FauSiebels M, Siebels M, Fau-Negrier S, Negrier S, FauChevreau $\mathrm{C}$, et al. Sorafenib in advanced clear-cell renal-cell carcinoma. N Engl J Med. 2007; 356:125-34. https://doi. org/10.1056/NEJMoa060655.

10. Brose MS, Nutting CM, Jarzab B, Elisei R, Siena S, Bastholt L, de la Fouchardiere C, Pacini F, Paschke R, Shong YK, Sherman SI, Smit JW, Chung J, et al. Sorafenib in radioactive iodine-refractory, locally advanced or metastatic differentiated thyroid cancer: a randomised, double-blind, phase 3 trial. Lancet. 2014; 384:319-28. https://doi. org/10.1016/S0140-6736(14)60421-9.

11. Wang Z, Hu J, Fau-Qiu SJ, Qiu SJ, Fau-Huang XW, Huang XW, Fau-Dai Z, Dai Z, Fau-Tan CJ, Tan CJ, Fau-Zhou J, Zhou J, Fau-Fan J, et al. An investigation of the effect of sorafenib on tumour growth and recurrence after liver cancer resection in nude mice independent of phosphorylated extracellular signal-regulated kinase levels. Expert Opin Investig Drugs. 2011; 20:1039-45. https://doi.org/10.1517 /13543784.2011.588598

12. Zhang W, Zhao G Fau-Wei K, Wei K, Fau-Zhang Q, Zhang Q, Fau-Ma W, Ma W, Fau-Song T, Song T, Fau-Wu Q, Wu Q, Fau-Zhang T, Zhang T, et al. Adjuvant sorafenib reduced mortality and prolonged overall survival and post-recurrence survival in hepatocellular carcinoma patients after curative resection: a single-center experience. Biosci Trends. 2014; 8:333-8. https://doi.org/10.5582/bst.2014.01120.

13. Wang SN, Chuang Sc Fau-Lee KT, Lee KT. Efficacy of sorafenib as adjuvant therapy to prevent early recurrence of hepatocellular carcinoma after curative surgery: A pilot study. Hepatol Res. 2014; 44:523-31. https://doi. org/10.1111/hepr.12159.

14. Zhuang L, Wei YG, Yang JY, Wen TF, Xu MQ, Yan LN, Li B. Efficacy analysis of sorafenib therapy after hepatectomy 
in treatment of intermediate and advanced hepatocellular carcinoma. Chinese Journal of General Surgery. 2014; 23:882-886. doi:10.7659/j.issn.1005-6947.2014.07.004

15. Li J, Hou Y, Cai XB, Liu B. Sorafenib after resection improves the outcome of BCLC stage $\mathrm{C}$ hepatocellular carcinoma. World J Gastroenterol. 2016; 22:4034-40. https://doi.org/10.3748/wjg.v22.i15.4034.

16. Chen BF, Pan CZ, Chen SX, Ling YB, Tang ZF, Xu RY, Pan WD. Clinical efficacy of sorafenib in preventing recurrence of primary liver cancer after radical surgery. Chin J Hepat Surg. 2016; 5:38-42. https://doi.org/10.3877/cma.j.is sn.2095-3232.2016.01.010.

17. Villanueva A, Newell P Fau-Chiang DY, Chiang Dy Fau-Friedman SL, Friedman Sl Fau-Llovet JM, Llovet JM. Genomics and signaling pathways in hepatocellular carcinoma. Semin Liver Dis. 2007; 27:55-76. https://doi. org/10.1055/s-2006-960171.

18. Keating GM, Santoro A. Sorafenib: a review of its use in advanced hepatocellular carcinoma. Drugs. 2009; 69:22340. https://doi.org/10.2165/00003495-200969020-00006.

19. Haas NB, Manola J, Uzzo RG, Flaherty KT, Wood CG, Kane C, Jewett M, Dutcher JP, Atkins MB, Pins M, Wilding G, Cella D, Wagner L, et al. Adjuvant sunitinib or sorafenib for high-risk, non-metastatic renal-cell carcinoma (ECOGACRIN E2805): a double-blind, placebo-controlled, randomised, phase 3 trial. Lancet. 2016; 387:2008-16. https://doi.org/10.1016/S0140-6736(16)00559-6.

20. Zafrakas M, Papasozomenou P, Emmanouilides C. Sorafenib in breast cancer treatment: A systematic review and overview of clinical trials. World J Clin Oncol. 2016; 7:331-6. https://doi.org/10.5306/wjco.v7.i4.331.

21. Yu SJ, Kim YJ. Hepatitis B viral load affects prognosis of hepatocellular carcinoma. World J Gastroenterol. 2014; 20:12039-44. https://doi.org/10.3748/wjg.v20.i34.12039.

22. Liu GM, Huang XY, Shen SL, Hu WJ, Peng BG. Adjuvant antiviral therapy for hepatitis B virus-related hepatocellular carcinoma after curative treatment: A systematic review and meta-analysis. Hepatol Res. 2016; 46:100-10. https://doi. org/10.1111/hepr.12584.

23. Shim JH, Jun MJ, Han S, Lee YJ, Lee SG, Kim KM, Lim YS, Lee HC. Prognostic nomograms for prediction of recurrence and survival after curative liver resection for hepatocellular carcinoma. Ann Surg. 2015; 261:939-46. https://doi.org/10.1097/SLA.0000000000000747.

24. Sumie S, Kuromatsu R Fau-Okuda K, Okuda K Fau-Ando E, Ando E Fau-Takata A, Takata A Fau-Fukushima N, Fukushima N Fau-Watanabe Y, Watanabe Y Fau-Kojiro M, Kojiro M Fau-Sata M, Sata M. Microvascular invasion in patients with hepatocellular carcinoma and its predictable clinicopathological factors. Ann Surg Oncol. 2008; 15:137582. https://doi.org/10.1245/s10434-008-9846-9.

25. Poon RT, Fan St Fau-Ng IO, Ng Io Fau-Lo CM, Lo Cm FauLiu CL, Liu Cl Fau-Wong J, Wong J. Different risk factors and prognosis for early and late intrahepatic recurrence after resection of hepatocellular carcinoma. Cancer. 2000; 89:500-7. https://doi.org/10.1002/1097-0142(20000801)89.
26. Li SH, Guo ZX, Fau-Xiao CZ, Xiao CZ, Fau-Wei W, Wei W, Fau-Shi M, Shi M Fau-Chen ZY, Chen ZY, Fau-Cai MY, Cai MY, Fau-Zheng L, Zheng L, et al. Risk factors for early and late intrahepatic recurrence in patients with single hepatocellular carcinoma without macrovascular invasion after curative resection. Asian Pac J Cancer Prev. 2013; 14:4759-63. https://doi.org/http://dx.doi.org/10.7314/ APJCP.2013.14.8.4759.

27. Uchibori K, Kasamatsu A, Fau-Sunaga M, Sunaga M, FauYokota S, Yokota S, Fau-Sakurada T, Sakurada T, FauKobayashi E, Kobayashi E, Fau-Yoshikawa M, Yoshikawa M, Fau-Uzawa K, et al. Establishment and characterization of two 5-fluorouracil-resistant hepatocellular carcinoma cell lines. Int J Oncol. 2012; 40:1005-10. https://doi. org/10.3892/ijo.2011.1300.

28. Shaul YD, Freinkman E, Comb WC, Cantor JR, Tam WL, Thiru P, Kim D, Kanarek N, Pacold ME, Chen WW, Bierie B, Possemato R, Reinhardt F, et al. Dihydropyrimidine accumulation is required for the epithelial-mesenchymal transition. Cell. 2014; 158:1094-109. https://doi. org/10.1016/j.cell.2014.07.032.

29. Chao Y, Wu Q Fau-Shepard C, Shepard C Fau-Wells A, Wells A. Hepatocyte induced re-expression of E-cadherin in breast and prostate cancer cells increases chemoresistance. https://doi.org/10.1007/s10585-011-9427-3.

30. Bielecka ZF, Czarnecka AM, Solarek W, Kornakiewicz A, Szczylik C. Mechanisms of Acquired Resistance to Tyrosine Kinase Inhibitors in Clear-Cell Renal Cell Carcinoma (ccRCC). Curr Signal Transduct Ther. 2014; 8:218-28. https://doi.org/10.2174/1574362409666140206223014.

31. Poulikakos PI, Zhang C Fau-Bollag G, Bollag G Fau-Shokat KM, Shokat Km Fau-Rosen N, Rosen N. RAF inhibitors transactivate RAF dimers and ERK signalling in cells with wild-type BRAF. Nature. 2010; 464:427-30. https://doi. org/10.1038/nature08902.

32. Ebos JM, Lee Cr Fau-Cruz-Munoz W, Cruz-Munoz W Fau-Bjarnason GA, Bjarnason Ga Fau-Christensen JG, Christensen Jg Fau-Kerbel RS, Kerbel RS. Accelerated metastasis after short-term treatment with a potent inhibitor of tumor angiogenesis. Cancer Cell. 2009; 15:232-9. https:// doi.org/10.1016/j.ccr.2009.01.021.

33. Sposito C, Mariani L, Fau-Germini A, Germini A, FauFlores Reyes M, Flores Reyes M, Fau-Bongini M, Bongini M, Fau-Grossi G, Grossi G, Fau-Bhoori S, Bhoori S, FauMazzaferro V, et al. Comparative efficacy of sorafenib versus best supportive care in recurrent hepatocellular carcinoma after liver transplantation: a case-control study. J Hepatol. 2013; 59:59-66. https://doi.org/10.1016/j. jhep.2013.02.026.

34. Hanahan D, Weinberg RA. Hallmarks of cancer: the next generation. Cell. 2011; 144:646-74. https://doi. org/10.1016/j.cell.2011.02.013.

35. Bruix J, Takayama T, Mazzaferro V, Chau GY, Yang J, Kudo M, Cai J, Poon RT, Han KH, Tak WY, Lee HC, Song $\mathrm{T}$, Roayaie S, et al. Adjuvant sorafenib for hepatocellular 
carcinoma after resection or ablation (STORM): a phase 3, randomised, double-blind, placebo-controlled trial. Lancet Oncol. 2015; 16:1344-54. https://doi.org/10.1016/S14702045(15)00198-9.

36. Lei J, Zhong J, Hao J, Liu Z, Zhang P, Wu L, Yan L, Zhu J, Zeng Y, Li B, Wen T, Wang W. Hepatocellular carcinoma cases with high levels of c-Raf-1 expression may benefit from postoperative adjuvant sorafenib after hepatic resection even with high risk of recurrence. Oncotarget. $2016 \mathrm{Jul} 5$; 7:42598-607. https://doi.org/10.18632/oncotarget.3799.

37. Zhang W, Zhao G, Fau-Wei K, Wei K, Fau-Zhang Q, Zhang Q, Fau-Ma W, Ma W, Fau-Wu Q, Wu Q, Fau-Zhang T, Zhang T, Fau-Kong D, et al. Adjuvant sorafenib therapy in patients with resected hepatocellular carcinoma: evaluation of predictive factors. Med Oncol. 2015; 32:107. https://doi. org/10.1007/s12032-015-0549-3.

38. Gang Z, Xi-Shan H, Tian-Qiang S. Efficacy of sorafenib as adjuvant therapy to hepatocellular carcinoma patients after hepatectomy. HPB Conference: 11th World Congress of the International Hepato-Pancreato-Biliary Association Seoul South Korea. 2014; 16.
39. Zheng PF, Liu HY, Ye YS, Li ZN, Li W. Outcomes of different treatments for patients with advanced hepatocellular carcinoma: a single center retrospective study. Chin J Hepatobiliary Surg. 2014; 20:781-785. https://doi. org/10.3760/cma.j.issn.1007-8118.2014.11.003.

40. Zhang HW, Lin SW, Wu CH, Chen YJ, Wang J. Analysis on prognostic factors of postoperative hepatocellular carcinoma patients treated with sorafinib. Lingnan Modern Clinics in Surgery. 2013; 13:14-17. https://doi.org/10.3969/ j.issn.1009-976X.2013.01.005.

41. Higgins JP, Altman Dg Fau-Gotzsche PC, Gotzsche Pc Fau-Juni P, Juni P Fau-Moher D, Moher D Fau-Oxman AD, Oxman Ad Fau-Savovic J, Savovic J Fau-Schulz KF, Schulz Kf Fau-Weeks L, Weeks L Fau-Sterne JAC, Sterne JA. The Cochrane Collaboration's tool for assessing risk of bias in randomised trials. BMJ. 2011; 343: d5928. https:// doi.org/10.1136/bmj.d5928.

42. Stang A. Critical evaluation of the Newcastle-Ottawa scale for the assessment of the quality of nonrandomized studies in meta-analyses. Eur J Epidemiol. 2010; 25:603-5. https:// doi.org/10.1007/s10654-010-9491-z. 